\title{
Managing the Learning Capacity of Organizational Culture in Relation to Organizational Commitment: Methodological and Empirical Overview
}

\begin{abstract}
The primary objective of the paper is to offer qualitative analysis based on the previous relevant theoretical and empirical work for the correlation between systematic and methodological implementation of organizational commitment throughout its learning capacity and organizational culture. The co-integration of the two critical issues stresses the significance and influence of contemporary and holistic models, such as, the OCTAPACE model, and its convergence to High Commitment management Model (HCM), as highly important for organizational growth and competitiveness of business entities.
\end{abstract}

Keywords: organizational culture, OCTAPACE model, organizational commitment, HCM.

Pagrindinis straipsnio tikslas yra pasiūlyti kokybinę analizę, pagrịstą ankstesniu atliktu teoriniu ir empiriniu tyrimu, siekiant suderinti sisteminị ir metodologinị organizacinių ịsipareigojimų vykdymą pasitelkiant organizacijos mokymosi gebejimus ir organizacinę kultūrą. Dviejų svarbių klausimų integravimas pabrěžia šiuolaikinių ir holistinių modelių, tokių kaip OCTAPACE modelis, svarbą ir ịtaką bei jų sąsajas su aukšto darbuotojų issipareigojimo organizacijai valdymo modeliu, kuris labai svarbus verslo organizaciniam augimui bei verslo subjektų konkurencingumui.

Raktiniai žodžiai: organizacinė kultūra, OCTAPACE modelis, organizacinis i̊sipareigojimas, aukšto darbuotojų įsipareigojimo organizacijai valdymo modelis.

\section{Introduction}

Nowadays organizations, analysed as business form of entities, are facing an increased and profound number of challenges that are related to the necessity of their external adaptation (focus/differentiation orientation) and internal integration (flexibility/ control orientation). Possession of sufficient resources and capacities is evidently not sufficient for obtaining a managerial system which would constantly develop the potential of placing the organizational culture in the central business framework and, furthermore, integrating it with the behavioural dimension of the organizational environment, such as organizational commitment. The tendency of managers to harmonize the process and behavioural segments of managing their prevalent business model is highly dependent on the organization's orientation to build and

Leonid NAKOV - PhD in organizational sciences (management), associate professor; Director of the Centre for Economic Researches (CER) at the Faculty of Economics, Ss. Cyril and Methodius University in Skopje, Republic of Macedonia. Address: Skopje, Bul Goce Delcev bb., Republic of Macedonia. Phone: +389 23286842. E-mail: lnakov@ eccf.ukim.edu.mk.

Igor IVANOVSKI - PhD in organizational sciences and finance (insurance and pensions), assistant professor at the Faculty of Economics, Ss. Cyril and Methodius University in Skopje, Republic of Macedonia. Address: Skopje, Bul Goce Delcev bb., Republic of Macedonia. Phone: +389 23286836. E-mail: ivanovski@eccf.ukim.edu.mk. 
sustain a model of organizational culture that is capable of identifying and permanently implementing the desired organizational changes directed towards improving the overall business effectiveness and efficiency. It is evident from the majority of researchers in the field of organizational culture (Lawson, 2003) that it is more than a basic pattern of values, beliefs, standards, norms, expectations, motives, needs etc., which aggregate at individual, group/ team and organizational level, mainly owing to the orientation of every advanced model of organizational culture to serve as a source for attaining competitive advantage and, furthermore, for the overall organizational identity.

The prior research object is focused on the holistic influence of the behavioural dimensions of the learning model of organizational culture, in the process of increasing the learning capacity of managing aimed at advancements in the integral elements of organizational culture, predominantly the values and beliefs. The connection of the proposed research object with the prevalent research problem is fundamentally placed at contemporary managerial challenges for enabling an in-depth, structural causality of organizational commitment and organizational culture, through the practices of Human Resource Management (HRM), analysed in terms of the significant variables of organizational culture.

With regard to the research goals, the paper integrates the following key research goals: a) identifying and analysing the function and importance of the learning organizational culture, from its inter-dependence with the organizational collaboration and commitment; b) empirical comparative modelling of the inter-dependence of transformative leadership and organizational commitment with the prevalent practices of Human Resource Management (HRM), having an ultimate goal of increasing the capacity for establishing a High Commitment Management model (HCM).

\section{Developing the learning organizational culture}

Each and every attempt to conceptualize the organizational culture should be followed by particular attention to the fact that, as a behavioural business concept, it does not exist and influence sufficiently the organizational performances if it is not properly 'fitted' within other implementing elements of the organizational strategy - structure and leadership style.

Fundamentally, organizational culture (Parrek, Rao, 1999) is perceived as $c u$ mulative, crystalized and quasi stable lifestyle of people as reflected in the presence of some states of life over others, in the response predispositions towards several significant issues and phenomena (attitudes), in the organized way of filling time in relation to certain affairs (rituals), and in the ways of promoting desired and preventing undesirable behaviour (sanctions). It is evident that the term implies the approach of understanding the work atmosphere, potential to act in a certain way, repetitive models of behaving while working and, in the end, restraining from the action manifestations that are not commonly understood and applied. As a multi-level behavioural concept, it is highly dependent on the organizational climate (Dwivedi, Kaushik and Luxmi, 2014), which is determined as the perceived attributes of an organization and its subsystems, as reflected in the way it deals with its members, associated groups, and issues. 
Organizational culture is a reflection of the core business assumptions and beliefs that govern the overall processes and objectives. However, the process of reframing and advancing the organizational culture depends on the learning potential of the organization, whereas learning (Rothwell, Cookson, 1997) as a continuous concept, will lead to performance improvement only when it is performance-enhancing and actually applied in the workplace, meaning it is oriented to application. The importance of the organizational learning process can be best illustrated through the learning process (Nonaka et al., 2001), fundamentally described as the foundational cornerstone of knowledge-creation practice which leads to collective knowledge - creation, which in turn, the created knowledge triggers another innovative learning process, possessing an iterative character.

A closer determination of the learning organizational culture emphasizes that, as one of the most advanced behavioural concepts that determines the organizational performances, it is defined (Garvin, 1993) as an organization skilled at creating, acquiring and transferring knowledge, and at modifying its behavior to reflect new knowledge and insights.

Learning organizational culture is created by harmonizing the following integral elements of learning (Watkins, Marsick, 1993) within the prevalent pattern of values, beliefs, standards and norms:

1. Continuous learning opportunities; 2. Inquiry and dialogue; 3. Collaboration and team learning; 4. Empowering people toward a collective vision; 5 . Systems to capture and share learning; 6 . Connect organization to its environment, and Strategic leadership for learning practices.

The importance of unifying the above elements is placed in the necessity of developing a model of organizational culture which would be able to influence certain behavioural performance concepts, such as organizational commitment.

\section{Managing the prior values and beliefs in the OCTAPACE model of organizational culture}

In order to increase the awareness for a higher level of business ethical dimensions within the learning model of organizational culture, an OCTAPACE cultural model (Pareek, 1997, 2002) has been developed, comprising of the most influential behavioural factors for the organizational successibility. An illustrative presentation of the elements of the OCTAPACE model of organizational culture is given in Figure 1 bellow:

Although primary implemented in the IT and banking sectors, this model is becoming increasingly popular in other sectors, such as the public sector, the SME's sector, etc. The applicative importance of the model lies in its capacity to influence one of the most popular organizational environment components in the field of Human Resource Development (HRD) that is inter-connected to the organizational changes, innovative process and performances, i.e., the organizational commitment.

\section{Influence of the learning organizational culture on organizational commitment}

Fundamentally, organizational commitment, somewhere stipulated as member identity (Robbins, 2005) is defined as a state in which an employee identifies with a particular organization and its goals, 


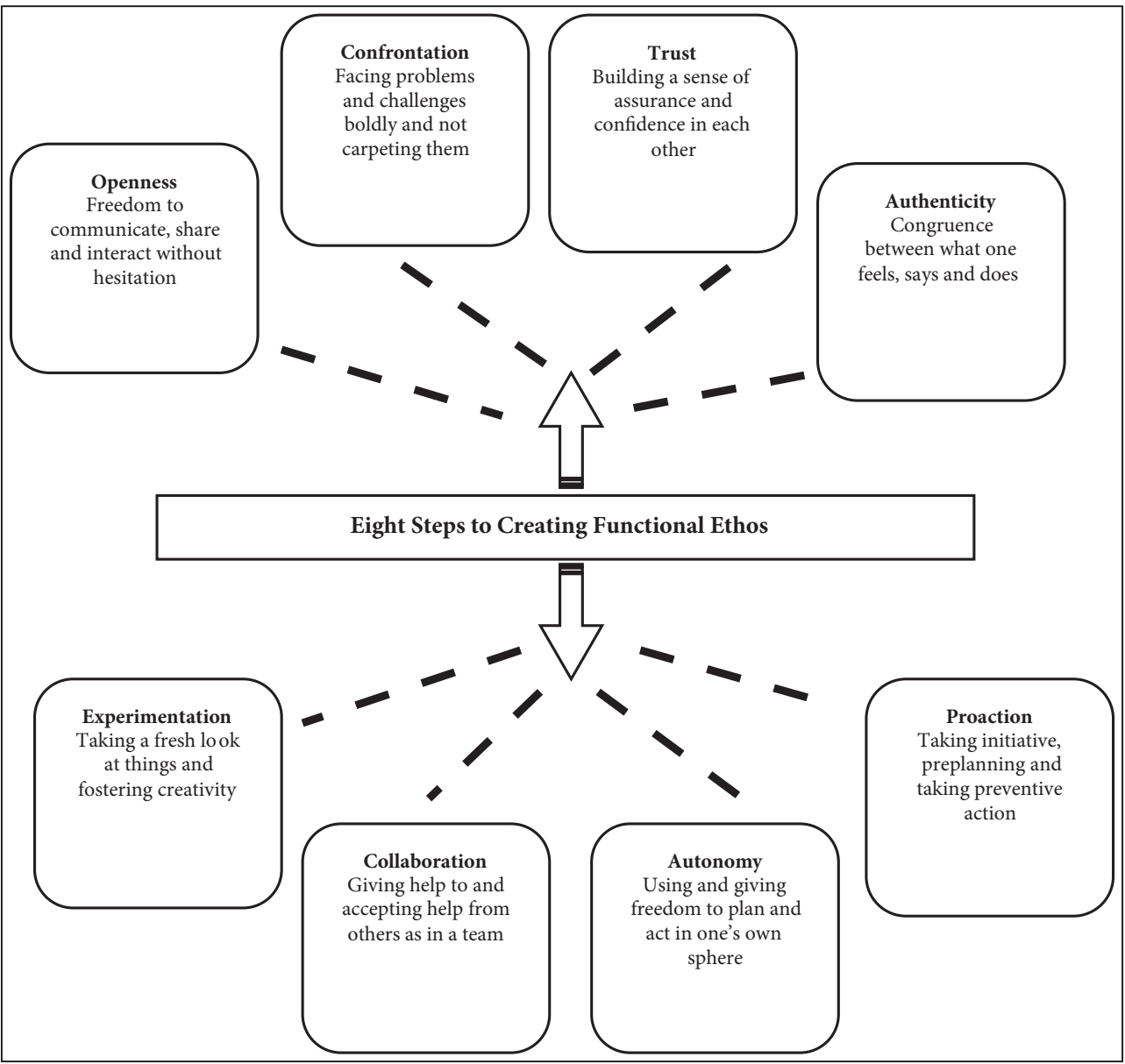

Fig. 1. Dimensions of the OCTAPACE model of organizational culture

Source: F. T. Azmi and R. Sharma (2007).

and wishes to maintain his membership in the organization. This contemporary definition is a continuation of the initial determination of the concept (Hall, Schneider and Nygfre, 1970) as the process by which the goals of the organization and those of the individual become increasingly integrated or congruent. Having in mind that the state to which every employee is feeling integrated within the organization, as an individual, group/team or as a whole organizational system, is far more than a normative concept, in practice it arises that organizational commitment comprises also of affective, psychological, continual, empathic, as well as learning component. For empirical purposes in the work, we would follow its affective, continuance and normative dimensions. In this context, certain authors, like R. A. Ghani et. al. (2004), state that employee with strong Organizational commitment continue employment with the organization, because they want to do so, enacting specific behaviors due to the belief that it is morally correct rather than 
personally beneficial. Learning organizational culture influences organizational commitment both directly - through the fundamental cultural values and beliefs and indirectly - through the practices of the Human Resource Development (HRD). Empirically, above relationship (Shannawaz and Hazarika, 2004) has empirically been tested on the OCTAPACE organizational culture scale, indicating that organizational culture is a significant predictor of the success of organizational commitment. One of the most challenging issues in managing the necessary organizational changes is undoubtedly the proper explanation of the relationship between the learning organizational culture and organizational commitment. Although certain experts, like T. Kassahun (2005), state that perceived job autonomy, procedural and distributive justice, organizational support and employee age are the most important predictors of organizational commitment. Another group, like P. A. Sungmin, B. Henkin and R. Egley (2005), clarify that far most important determinants are trust and potential for team work - illustrated through cooperation. Besides, other authors, like J. Connel, N. Ferres and A. Travaglione (2003), state that organizational support, transformational leadership and procedural justice are the central factors for the organizational commitment success.

In order to detail the constitutive elements of dimensions of the organizational culture which influence organizational commitment, the analysis will be focused on the influencing potential of Collaboration (Dwivedi, Kaushik, Luxmi, 2014), which, in fact, consists of enhanced team spirit, sharing of experiences, improved communication, timely help and improved resource sharing. Organizational culture happens to be an intermediary influencing factor to organizational commitment, starting from leadership and ending with the organizational performance which results from organizational commitment. In the empirical segment of our work, their influence on organizational commitment will be regionally and internationally tested. The findings of the analyses are the cornerstone pathway for undertaking the same empirical research in several regional South-eastern European countries, including the Republic of Macedonia. In order to bear a managerial dimension, organizational commitment must be systematically managed and further developed, a need that is undertaken with the implementation of the High Commitment Management model (HCM). Fundamentally, HCM (Purcell, 1993) is determined as the visual embodiment of the unitarist frame of reference, both in the sense of legitimation of managerial authority and in the imagery of the firm as a team with committed employees working with managers for the benefit of the firm. HCM is created with an aim to promote organizational commitment, in order to harmonize between the organizational and employee objectives.

\section{Empirical analyses of the mutual relationship of organizational culture and organizational commitment}

Even though a thorough examination of the correlation between organizational culture and organizational commitment has gained importance over the past two decades, there is still limited number of profound national and international surveys and empirical analyses, as a base for determining the applicability 
of theoretical proofs. In order to test and validate the above given theoretical orientations, in this empirical part, we are referring to certain prominent empirical work done on a comparable basis. Furthermore, we seek to stress the initiative for empirical study, based on our created theoretical model for national or regional, South-eastern European countries, level. We particularly point out that most of the analysed empirical work has been done at national level, and frequently is segmented across the business sector, a moment that raises dilemma for its entire applicability, as a general process for all institution types. Credible results can be found in the work of S. Dwivedi, S. Kaushik and Luxmi (2014), that examined the link between organizational commitment and organizational culture in the Business Process Outsourcing (BPO) in Indian economy, with an excessive usage of the OCTAPACE cultural model. The authors selected 15 out of $40 \mathrm{BPO}$ units in the final stage of their analysis, in which they have evaluated Questionnaires on 524 employees at three levels - top, middle and lower level. They have made a selection of 15 BPO units with different industry profile and number of employees, creating three strata, i.e., BPO units up to 250 , from 250 up to 500 and over 500 employees. Fundamental analytical conclusions regarding the tested relationship are the following: firstly, there is differentiation in the perception of the employees in the three strata about organizational culture in terms of more positive perception in the smaller $B P O$ units than in the following middle and larger $B P O$ s. In this regard, they conclude through ANOVA testing that there is no difference in the perception of the dimensions of organizational culture, openness, authenticity, autonomy and collaboration. However, the other case is with the dimensions of confrontation, trust, proaction and experimentation, as the employees' perception of them differs (Table 1), confirming the first results that employees in smaller companies understand and perceive organizational culture and some of its dimensions more closely compared to other BPO units in the second and third stratum.

Table 1. Analysis of variance (ANOVA) of dimensions of organizational culture in three organizational strata of BPO units (under study)

\begin{tabular}{|c|c|c|c|c|c|c|c|c|c|c|c|c|c|c|c|c|c|}
\hline \multirow[t]{2}{*}{ Strata } & \multirow[t]{2}{*}{$\mathbf{N}$} & \multicolumn{2}{|c|}{ Openness } & \multicolumn{2}{|c|}{$\begin{array}{c}\text { Confronta- } \\
\text { tion }\end{array}$} & \multicolumn{2}{|c|}{ Trust } & \multicolumn{2}{|c|}{$\begin{array}{l}\text { Authenti- } \\
\text { city }\end{array}$} & \multicolumn{2}{|c|}{ Proaction } & \multicolumn{2}{|c|}{ Autonomy } & \multicolumn{2}{|c|}{$\begin{array}{c}\text { Collabora- } \\
\text { tion }\end{array}$} & \multicolumn{2}{|c|}{$\begin{array}{l}\text { Experimen- } \\
\text { tation }\end{array}$} \\
\hline & & $\stackrel{\Xi}{\stackrel{\Xi}{\Sigma}}$ & 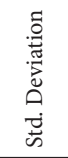 & $\stackrel{\text { है }}{\stackrel{\Xi}{\Sigma}}$ & 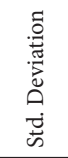 & $\stackrel{\Xi}{\stackrel{\Xi}{\Sigma}}$ & 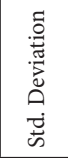 & $\stackrel{\text { శ్ }}{\stackrel{\Xi}{\Sigma}}$ & 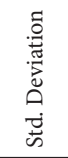 & $\stackrel{\text { ॠే }}{\stackrel{\Xi}{\Sigma}}$ & 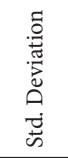 & $\stackrel{\text { శ్ }}{\stackrel{\Xi}{\Sigma}}$ & 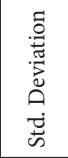 & 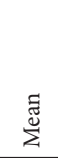 & 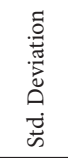 & 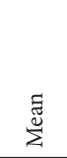 & 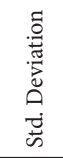 \\
\hline I & 240 & & 0.476 & 2.40 & 0.423 & 2.42 & 0.500 & 2.19 & 0.390 & 2.57 & 0.596 & 2.17 & 0.348 & 2.43 & 0.422 & 2.50 & 0.53 \\
\hline II & 136 & 2.33 & 0.525 & 2.25 & 0.589 & 2.28 & 0.577 & 2.21 & 0.378 & 2.29 & 0.561 & 2.14 & 0.483 & 2.42 & 0.466 & 2.27 & 0.486 \\
\hline III & 148 & & 0.511 & & 0.459 & 2.30 & & 2.22 & & 2.47 & & 2.22 & & 2.38 & 0.455 & 2.32 & 0.515 \\
\hline Total & 524 & 2.37 & 0.500 & 2.32 & 0.485 & 2.35 & 0.535 & 2.20 & 0.393 & 2.47 & 0.614 & 2.18 & 0.405 & 2.41 & 0.443 & 2.39 & 0.528 \\
\hline \multicolumn{2}{|c|}{ ANOVA } & \multicolumn{2}{|c|}{$\begin{array}{c}\text { F-Value: } \\
2.621 \\
(\mathrm{p}=0.074)\end{array}$} & \multicolumn{2}{|c|}{$\begin{array}{c}\text { F-Value: } \\
5.240 \\
(\mathrm{p}=0.006)\end{array}$} & \multicolumn{2}{|c|}{$\begin{array}{c}\text { F-Value: } \\
3.464 \\
(\mathrm{p}=0.032)\end{array}$} & \multicolumn{2}{|c|}{$\begin{array}{c}\text { F-Value: } \\
0.408 \\
(\mathrm{p}=0.665)\end{array}$} & \multicolumn{2}{|c|}{$\begin{array}{c}\text { F-Value: } \\
9.449 \\
(\mathrm{p}=0.000)\end{array}$} & \multicolumn{2}{|c|}{$\begin{array}{c}\text { F-Value: } \\
1.327 \\
(\mathrm{p}=0.266)\end{array}$} & \multicolumn{2}{|c|}{$\begin{array}{c}\text { F-Value: } \\
0.823 \\
(\mathrm{p}=0.440)\end{array}$} & \multicolumn{2}{|c|}{$\begin{array}{c}\text { F-Value: } \\
10.277 \\
(\mathrm{p}=0.000)\end{array}$} \\
\hline
\end{tabular}

Source: S. Dwivedi, S. Kaushik, and Luxmi (2014). 
Secondly, the most important data can be seen in the authors' correlation and regression analysis, treating the relationship between organizational commitment and the dimensions of organizational culture. In this case, there is significant Pearson correlation between the commitment and the eight organizational culture dimensions for all three strata of employees, pointing the proaction as the dimension with the strongest correlation and autonomy with the weakest correlation (Table 2).

These results served as a basis for the regression model, in which organizational commitment was a dependent variable (Table 3). The findings confirmed that the dimensions of organizational culture are predicting the perception, model and implementation of employees' organizational commitment, with exclusion of the dimension of openness and autonomy. Regarding the role of cooperation as an element of the OCTAPACE model, we must note that even though it has one of the highest correlation coefficients, yet, in the regression model, its influence and statistical significance is among the lowest one, as our most important future research challenge. In addition, the under average coefficient of determination that amounts to $31.5 \%$ of the population, does not allow too much space for general empirical conclusions.

Other scholars (Simosi, Xenikou, 2010), in a survey and empirical study of a Greek service company, examined the influence of organizational culture, particularly the role of leadership in the employees' commitment - a methodological

Table 2. Correlation between organizational culture and organizational commitment

\begin{tabular}{|l|c|c|c|c|c|c|c|c|}
\hline & $\begin{array}{c}\text { Open- } \\
\text { ness }\end{array}$ & $\begin{array}{c}\text { Confron- } \\
\text { tation }\end{array}$ & Trust & $\begin{array}{c}\text { Authen- } \\
\text { ticity }\end{array}$ & $\begin{array}{c}\text { Pro- } \\
\text { action }\end{array}$ & $\begin{array}{c}\text { Autono- } \\
\text { my }\end{array}$ & $\begin{array}{c}\text { Collabo- } \\
\text { ration }\end{array}$ & $\begin{array}{c}\text { Experimenta- } \\
\text { tion }\end{array}$ \\
\hline Commitment & $0.346^{* *}$ & $0.418^{* *}$ & $0.392^{* *}$ & $0.299^{* *}$ & $0.481^{* *}$ & $0.151^{* *}$ & $0.309^{* *}$ & $0.384^{* *}$ \\
\hline & 0.000 & 0.000 & 0.000 & 0.000 & 0.000 & 0.001 & 0.000 & 0.000 \\
\hline
\end{tabular}

Note: Pearson Correlation (only significant correlations are displayed).

${ }^{* *}$ Correlation is significant at 0.05 levels.

Source: S. Dwivedi, S. Kaushik, and Luxmi (2014).

Table 3. Step-wise regression analysis - organizational commitment

\begin{tabular}{|c|c|c|c|c|c|}
\hline Dimensions & $\begin{array}{c}\text { Standardized } \\
\text { Coefficients } \\
\text { (Beta) }\end{array}$ & $\mathbf{t}$ & Sig. & $\begin{array}{c}\text { Regression } \\
\text { Model }\end{array}$ & Summary \\
\hline (Constant) & & 10.951 & 0.000 & Adjusted $\mathrm{R}^{2}=$ & 0.315 \\
\hline Proaction & 0.162 & 3.225 & 0.001 & Durbin Watson= & 1.902 \\
\hline Confrontation & 0.140 & 3.183 & 0.002 & ANOVA(F) & 41.148 \\
\hline Experimentation & 0.152 & 3.440 & 0.001 & Sig. & 0.000 \\
\hline Authenticity & 0.135 & 3.508 & 0.000 & & \\
\hline Collaboration & 0.118 & 2.884 & 0.004 & & \\
\hline Trust & 0.123 & 2.797 & 0.005 & & \\
\hline
\end{tabular}

Source: S. Dwivedi, S. Kaushik, and Luxmi (2014). 
representative constraint, consisted of 300 employees, distributed by their age, gender and more important by the position (55\% non-managers and $45 \%$ managers) and length of service $(74 \%>4$ years and $24 \%<4$ years). They examined the employees' dimensions of commitment, i.e., affective, continuance and normative. The researchers placed the elements of transformational leadership and contingent reward behaviour, as well as humanistic, affiliative, achievement and self-actualization culture orientations as additional variables to the main three dimensions. The results of correlation analyses (Table 4) showed positive and statistically significant correlation between transformational leadership and contingent reward regarding the cultural orientations to affective and normative commitment, whilst there is low correlation the aspects of cultural influence to continuance commitment, i.e., personal sacrifice and perceived alternatives.
Correlation data was used in the analysis for creation of the two regression model evaluating the influence between transformational leadership and contingent reward, jointly with cultural orientations on the affective and normative commitment. The regression analysis confirmed, with different significance, positive correlation of leadership behaviour and contingent reward to the dimensions of organizational commitment.

In our opinion, the most important analytical conclusions of this second study are the following ones:

Firstly, the positive correlation between transformational leadership and contingent reward to affective and normative commitment, and this can be interpreted as an organizational environment in which transformational leaders have created conditions for fairness, performancebased expectations and achievements, while contingent reward behaviour is

Table 4. Correlation coefficients of the variables

\begin{tabular}{|c|c|c|c|c|c|c|c|c|c|c|}
\hline Variables & (1) & (2) & (3) & (4) & (5) & (6) & (7) & (8) & (9) & (10) \\
\hline $\begin{array}{l}\text { Affective Commitment (1) } \\
\text { Normative }\end{array}$ & - & & & & & & & & & \\
\hline $\begin{array}{l}\text { Commitment (2) Con- } \\
\text { tinuance commitment: }\end{array}$ & $.49^{* * *}$ & - & & & & & & & & \\
\hline $\begin{array}{l}\text { Personal sacrifice (3) Con- } \\
\text { tinuance commitment: }\end{array}$ & $.27^{* * *}$ & $.40^{* * *}$ & - & & & & & & & \\
\hline Perceived alternatives (4) & $-.14^{*}$ & $.03+$ & $.26^{* * *}$ & - & & & & & & \\
\hline $\begin{array}{l}\text { Transformational Leader- } \\
\text { ship (5) }\end{array}$ & $.15^{*}$ & $.20^{* *}$ & $.13+$ & $.05+$ & - & & & & & \\
\hline Contingent Reward (6) & $.25^{* * *}$ & $.30^{* * *}$ & $.19^{* *}$ & $-.004+$ & $.84^{* * *}$ & - & & & & \\
\hline Humanistic Culture (7) & $.30^{* * *}$ & $.35^{* * *}$ & $.25^{*}$ & $-.003+$ & $.57^{* * *}$ & $.55^{* * *}$ & - & & & \\
\hline Affiliative Culture (8) & $.26^{* * *}$ & $.28^{* * *}$ & $.15^{*}$ & $.04+$ & $.56^{* * *}$ & $.52^{* * *}$ & $.88^{* * *}$ & - & & \\
\hline Achievement Culture (9) & $.28^{* * *}$ & $.32^{* * *}$ & $.16^{* *}$ & $.03+$ & $.63^{* * *}$ & $.51^{* * *}$ & $.82^{* * *}$ & $.77^{* * *}$ & - & \\
\hline $\begin{array}{l}\text { Self-actualizing Culture } \\
\text { (10) }\end{array}$ & $.24^{* * *}$ & $.25^{* * *}$ & $.11+$ & $.06+$ & $.59^{* * *}$ & $.52^{* * *}$ & $.80^{* * *}$ & $.78^{* * *}$ & $.79^{* * *}$ & - \\
\hline
\end{tabular}

Notes: $\mathrm{N}=300 ;{ }^{*} \mathrm{p} \leq .05 ;{ }^{* *} \mathrm{p} \leq .01 ;{ }^{* * *} \mathrm{p} \leq .001$.

Source: M. Simosi and A. Xenikou (2010). 
likely inspiring the feeling of honesty, faith and trust among employees.

Secondly, their models, did not get the full picture of the impact of transformational leadership on continuance commitment, since only the element of personal sacrifice was linked to contingent reward, probably as a result of turbulent economic surrounding, economic crisis and midterm instability, to which employees react with their determination to keep membership in its organization.

And thirdly, limited correlation between organizational culture and organizational commitment, is followed by the authors' conclusion that the more employees perceive their organization as a group that promotes social support and constructive interpersonal relations, goal achievement and self-actualization, the more they would remain in the same organization, exercising moral reciprocity towards it.

\section{Conclusions}

The tendency of managers to harmonize the process and behavioural segments of managing their prevalent business model is highly dependent on the organizations' orientation to build and sustain a model of organizational culture that is capable of identifying and permanently implementing the desired organizational changes directed towards improving the overall business effectiveness and efficiency. Fundamentally, organizational culture is perceived as cumulative, crystalized and quasi stable life-style of people as reflected in the presence of some states of life over others, in the response predispositions towards several significant issues and phenomena (attitudes), in the organized way of filling time in relation to certain affairs (rituals), and in the ways of promoting the desired and preventing the undesirable behaviour (sanctions). A closer determination of the learning organizational culture emphasizes that, as one of the most advanced behavioural concepts that determines the organizational performances, it is defined as an organization skilled at creating, acquiring and transferring knowledge, and at modifying its behaviour to reflect new knowledge and insights.

In order to increase the awareness for a higher level of business ethical dimensions within the learning model of organizational culture, an OCTAPACE cultural model has been developed, comprising of the most influential behavioural factors necessary for the organizational success.

Organizational commitment, somewhere stipulated as member identity, is defined as a state in which an employee identifies herself/himself with a particular organization and its goals, and wishes to maintain her/his membership in the organization. The learning organizational culture influences organizational commitment both directly - through the fundamental cultural values and beliefs and indirectly - through the practices of $\mathrm{Hu}$ man Resource Development (HRD).

As a brief conclusion to the relationship of organizational culture and commitment, the first empirical analysis performed by S. Dwivedi, S. Kaushik and Luxmi made a pioneer attempt to test the correlation between organizational culture and its dimensions with organizational commitment. Their findings are conclusive and affirmative for the role of organizational commitment in the companies' functioning and growth. Even though they are limited in business profile as well as in location, the empirical study is a 
solid base for national and international studies of this kind.

As a conclusion to the second analysed study, conducted by M. Simosi and A. Xenikou, we can say that the authors made a sound study which, even with the systematic limitations of the non-causality possibility, as a cross-sectional analysis has been used, confirmed the previous empirical and theoretical conclusions.
Fundamentally, a serious role of the four cultural orientations to organizational commitment stresses the role of organizational culture and the positive role of leaders who inspire the follower's creativity, initiative, promote organizational context and align personal to organizational principles, in raising the employee's emotional attachment to the group and organization itself.

\section{References}

1. Azmi, F. T., Sharma, R. (2007). Profiling the OCTAPACE Culture: An Empirical Study of Banking and IT Sector in India // The Icfaian Journal of Management Research. Vol. 17, No. 12, pp. 7-9.

2. Connell, J., Ferres, N., Travaglione, A. (2003). Trust in the Workplace: Importance of Interpersonal and Organizational Support // Management Research News. Vol. 3, No. 2, pp. 113-118.

3. Dwivedi, S., Kaushik, S., Luxmi. (2014). Impact of on Commitment of Employees: An Empirical Study of BPS Sector in India // Vikalpa. Vol. 39, No. 3, pp. 77-92. doi: $10.1177 \% 2$ F0256090920140306.

4. Garvin, D. A. (1993). Building a Learning Organization. Harvard Business Review. Vol. 73, No. 4, pp. 78-91.

5. Ghani, R. A., Nordin, F., Mamat, L. (2004). Organizational Commitment Among the Academic Staff in the Distance Education Program // The International Journal of Education Development. Vol. 1, pp. 29-43.

6. Hall, D. T., Schneider, B., Nygfren, H. T. (1970). Personal Factors in Organizational Identification. Administrative Science Quarterly. Vol. 15, No. 2, pp. 176-190.

7. Dierkes, M., Berthoin Antal, A., Child, J., Nonaka, I. (2003). Handbook of Organizational Learning and Knowledge. - Oxford: Oxford University Press.

8. Joo, B. K., Shim, J. H. (2010). Psychological Empowerment and Organizational Commitment: The Moderating Effect of Organizational Learning Culture // Human Resource Development International. Vol. 13, No. 4, pp. 425-441. doi. org/10.1080/13678868.2010.501963.
9. Kassahun, T. (2005). Level of Organizational Commitment: Its Correlates and Predictors // Indian Journal of Industrial Relations. Vol. 41, No. 1, pp. 301-317.

10. Kjaergaard, L. A. (2009). Organizational Identity and Strategy: An Empirical Study of Organizational Identity's Influence on the Strategy-Making Process // International Studies of Management \& Organization. Vol. 39, No. 1, pp. 50-69. doi: 10.2753/IMO0020-8825390103.

11. Lawson, S. (2003). Examining the Relationship Between Organizational Culture and Knowledge Management. - PhD diss., Nova Southeastern University.

12. Simosi, M., Xenikou, A. (2010). The Role of Organizational Culture in the Relationship Between Leadership and Organizational Commitment: An Empirical Study in a Greek Organization // The International Journal of $\mathrm{Hu}$ man Resource Management. Vol. 21, No. 10, pp. 1598-1616. doi.org/10.1080/09585192.201 0.500485 .

13. Nonaka, I., Dierkes, M., Berthoin Antal, A., Child, J. (2001). A Theory of Organizational Knowledge Creation: Understanding the Dynamic Process of Creating Knowledge. In / Handbook of Organizational Learning and Knowledge. Part V: Processes of Organizational Learning and Knowledge Creation. - Oxford: Oxford University Press.

14. Padma, R. N., NairSumitha, V. (2009). Organizational Culture and its Impact on Organizational Commitment in Public and Private Organizations // Global Management Review. Vol. 4, No. 1, pp. 32-39. 
15. Pareek, U., Rao, T. V. (1999). Designing and Managing Human Resource Systems. - New Delhi: Oxford University Press.

16. Pareek, U. (1997). Training Instruments for Human Resource Development. - New Delhi: Tata McGraw-Hill Publishing Company.

17. Pareek, U. (2002). Training Instruments in HRD and OD. - New Delhi: Tata McGraw-Hill.

18. Purcell, J. (1993). The Challenge of Human Resource Management for Industrial Relations Research and Practice // International Journal of Human Resource Management. Vol. 4, No. 3, pp. 511-527. doi: 10.1080/09585199300000034.

19. Robbins, S. P. (2005). Organizational Behavior: Concepts, Controversies and Applications. 6th ed. - Englewood Cliffs, NJ: Prentice Hall.

20. Rothwell, W. J., Cookson, R. (1997). Beyond Instruction: Comprehensive Program Planning for Business and Education. - San Francisco: Jossey-Bass.

21. Shannawaz, MG., Hazarika, N. (2004). Organizational Commitment and Organization
Culture: A Study of Two Hospitals in Assam // Journal of Indian Academy of Applied Psychology. Vol. 30, No. 2, pp. 24-130.

22. Simosi, M., Xenikou, A. (2010). The Role of Organizational Culture in the Relationship between Leadership and Organizational Commitment: An Empirical Study in a Greek Organization // The International Journal of Human Resource Management. Vol. 21, No. 10, pp. 1598-1616. doi: 10.1080/09585192.2010.500485.

23. Park, S., Henkin, A. B., Egley, R. (2005). Teacher Team Commitment, Teamwork and Trust: Exploring Associations // Journal of Educational Administration. Vol. 43, No. 5, pp. 462-479. doi: 10.1108/09578230510615233.

24. Watkins, K. E., Marsick, V. J. (1993). Sculpting the Learning Organization: Lessons in the Art and Science of Systemic Change. - San Francisco: Jossey-Bass.

The paper submitted: September 9, 2018 Prepared for publication: December 10, 2018

Leonid NAKOV, Igor IVANOVSKI

\section{ORGANIZACINĖS KULTŪROS MOKYMOSI GEBĖJIMỤ VALDYMAS PASITELKIANT ORGANIZACIN! ISIPAREIGOJIMĄ: METODOLOGINĖ IR EMPIRINĖ APŽVALGA}

\section{$\mathrm{S}$ a n t r a u k a}

Šiuolaikinių verslo subjektų elgesys yra orientuotas $\mathfrak{i}$ tendenciją sukurti integruotą organizacinès kultūros plètros modeli, kuris suvienytu ankstesnes vertybes, požiūrị, ịsitikinimus, standartus ir normas, siekiant bendrų verslo tikslų. Šiame kontekste organizacinès kultūros OCTAPACE modelio planavimas ir igyvendinimas yra procesas, kuris pabrèžia ir toliau tobulina organizacinès kultūros mokymosi elgsenos gebejjimus bei daugiausia siekia didinti organizacinio ịsipareigojimo gyvybingumą. Pagrindinis šios tarpusavio priklausomybès tikslas - suformuoti aukšto darbuotojų įsipareigojimo valdymo modeli.

Vidinio organizacinio issipareigojimo modelio sukūrimas, igyvendinimas ir tobulinimas yra esminis žingsnis link tvaraus organizacinès kultūros modelio, kuris apima visus elementus ir susieja juos su įmonių organizacinio augimo samprata. Šiuo požiūriu organizacinis elgesys ir tvarus vadovavimas yra svarbūs veiksniai, kurie šiuo metu numato organizacinius ịsipareigojimus ir veliau organizacinę kultūrą kaip vieną iš efektyviausių vidinių elementų siekiant sukurti įmonių konkurencinį pranašumą. Be to, empiriniai tyrimai patvirtina teorines išvadas ir pateikia esmines gaires, paveikiančias tam tikrą organizacinès kultūros ịvairovę ir orientavimąsi ị organizacinị augimą, o tai leidžia dar labiau keisti ir transformuoti visus organizacinès plètros subjektus.

Holistinis požiūris ir kūrybinis derinimas bei organizacinès kultūros metmenų ir orientacijų rekombinacija yra papildomas svarbus veiksnys inicijuojant ir išlaikant organizaciniam augimui ir organizacinei kultūrai pritaikomą įtaką, o ne praktika, orientuota $\mathfrak{i}$ trumpalaikius prioritetus ar lūkesčius. Vidinès integracijos ir išorès prisitaikymo prie vyraujančios sektorinès organizacijos kultūros tendencijų sinchronizavimas turètų būti grindžiamas konkrečių subjektų pasiryžimu keisti ir nustatyti dinaminès aplinkos ir konkurencinio spaudimo metmenų derinị.

Metodologinès ir empirinès analizès bei organizacinès kultūros komponentų ir organizacinio įsipareigojimo tarpusavio priklausomybès regioniniu ir tarptautiniu lygmeniu integracija yra mokslinè 
tarpusavyje susijusių verslo subjektų, priklausančių Balkanų regionui, įskaitant Makedonijos Respubliką, santykių ir įtakos riba. Tai svarbu, ypač atsižvelgiant i pažeidžiamumą ir konkurencingumo bei produktyvumo stoką, taip pat ir ị tai, kad nèra stiprių ir tvarių vidaus procesų, skirtų ūkio subjektams valdyti, atsižvelgiant ị rinkos pažeidimus, riziką ir institucinị nestabilumą regione, kuris iš esmés mažina ir taip mažą vietos ir regiono verslo konkurencingumą, palyginti su Europos Sąungos bendrosios rinkos konkurencingumu. 